\title{
Assortative Mating and Divorce: Evidence from Austrian Register Data*
}

\author{
WOLFGANG FRIMMEL \\ University of Linz
}

\author{
MARTIN HALLA \\ University of Linz \& IZA
}

\author{
RUdolf Winter-EBMER \\ University of Linz, IHS, \\ CEPR \& IZA
}

June 26, 2012

\begin{abstract}
We show that changes in assortative mating patterns along the dimensions of age, ethnicity, religion and education are not responsible for the increasing marital instability over the last four decades in Austria. Without the rise in the age at marriage, divorce rates would be considerably higher. Immigration and secularization, and the resulting supply of spouses with diverse ethnicity and religious denominations had no overall effect on divorce rates. Countervailing effects - in line with theoretical predictions - offset each other. The rise in the incidence in divorce is most probably caused by increased social acceptance of divorce.
\end{abstract}

JEL Classification: J12, J11, J15, Z12, D1, R2.

Keywords: Assortative mating, divorce, marital instability, immigration.

\footnotetext{
${ }^{*}$ Corresponding author: Rudolf Winter-Ebmer, Johannes Kepler University of Linz, Department of Economics, Altenbergerstr.69, 4040 Linz, ph.: +43702468 8236, fax: +437024688217, email: rudolf.winterebmer@jku.at. For helpful discussion and comments we would like to thank two anonymous referees, the Editors Arnaud Chevalier and Antony Fielding, René Böheim, Raj Chetty, Enrico Moretti and Andrea Weber. This paper was partly written during Martin Halla's and Rudolf Winter-Ebmer's visiting scholarship at the Center for Labor Economics at the University of California, Berkeley. They would like to thank for the stimulating academic environment and hospitality there. Financial support from the Austrian Science Fund (FWF): National Research Network S103 is gratefully acknowledged.
} 


\section{Introduction}

The family in the western world has been radically altered over the last decades. Besides the drop in marriage rates and the increasing number of children born out of wedlock the increasing incidence of divorce which has been observed in most countries is sometimes considered as the most dramatic and far-reaching change (Amato, 2000).

A large body of research across academic disciplines has documented a strong negative correlation between divorce and a wide range of outcomes (Kitson and Morgan, 1990; Amato, 2000). For instance, compared with married individuals, divorced individuals have lower levels of economic well-being (e.g. Aassve, Betti, Mazzuco and Mencarini, 2007) and do worse along many psychological (e.g. Blanchflower and Oswald, 2004) and health dimensions (e.g. Richards, Hardy and Wadsworth, 1997). Policy-makers and scholars are especially concerned about negative consequences of divorce for affected children. Many papers consistently show that children of divorced parents tend to fare worse compared to children from continuously married parents. For instance, Gruber (2004) finds that they have lower educational attainment, lower incomes, marry earlier but separate more often, and have higher odds to commit suicide.

The potential negative consequences of divorce have spurred efforts to identify the causes for (increased) marital instability. However, since the dramatic increase in divorce rates came along with increased economic independence of women and radical changes in divorce law the causal link between demographic, economic and legal changes is non-trivial. So far, the economic literature has mainly focused on changes in divorce (Peters, 1986; Allen, 1992; Peters, 1992; Friedberg, 1998; Wolfers, 2006; González and Viitanen, 2009) and custody law (Halla, forthcoming). These papers have furthered our understanding of the effect of family law on intra-household-bargaining and explained part of the changes in family formation, dissolution and behaviour within marriage over the last decades. However, a large part of the changing divorce behaviour over time is still unexplained.

Another strand of literature analyses whether certain combinations of spouses' characteristics can explain the likelihood of divorce. This question can be directly linked to economic theory, which regards marriage as a voluntary partnership for the purpose of joint production and joint consumption. The so-called marriage market determines the assignment of partners and the sharing of the gains of marriage (Becker, 1993; Ermisch, 2003). Traditionally, economists have emphasised the importance of joint production and have shown that an efficient marriage market is usually characterised by the match of spouses with similar characteristics (e.g. by intelligence and physical attractiveness); see, for instance, Stevenson and Wolfers (2007). This so-called positive assortative mating enhances complementarities in household production and may reinforce the intergenerational persistence of wealth, income, education, and other economic outcomes. In contrast, negative assortative mating is optimal for traits that are substitutes in household production (e.g. wage earning power). Sociologists (e.g. Kalmijn, 1998) refer to the matching of homogenous spouses as endogamy (marriage to the same type) or homogamy (marriage to 
a similar type). They study these phenomena in order to understand how societies change over time, and to illuminate important social processes, such as the family's ability to pass on group values.

Scholars in both disciplines have focused on four dimensions of spouses' characteristics: (i) age, (ii) ethnicity, (iii) religious denomination and (iv) education. As predicted by theory (Becker, Landes and Michael, 1977) an empirical literature has shown that assortative mating along these dimensions is important for a successful duration of a marriage. A higher age at first marriage is known to decrease the likelihood of divorce and differences in religion and ethnicity are associated with a higher risk of divorce (e. g. Lehrer and Chiswick, 1993; Kalmijn, de Graaf and Janssen, 2005). The effect of education is theoretically ambiguous and empirical estimates vary across countries and time (Haerkoenen and Dronkers, 2006).

Others have looked at changes in assortative mating patterns over time. Most of the literature focuses on the U.S. (see, for instance, Kalmijn, 1991b, a; Mare, 1991; Pencavel, 1998; Smits, Ultee and Lammers, 2000; Schwartz and Mare, 2005; Bodenhorn, 2006; Gullickson, 2006). Most recently, Rosenfeld (2008) concludes that racial endogamy has declined sharply over the 20th century. Nevertheless, race is still the most powerful division in the U.S. marriage market. The development of religious endogamy is diverse; while the division between Jews and Christians is still strong, the division between Catholics and Protestants has weakened over time (Rosenfeld, 2008). Educational homogamy has increased over recent decades. This uniform trend was driven by different portions of the education distribution in different periods (Schwartz and Mare, 2005). Finally, a sharp rise in the age at first marriage can be observed. Among OECD-member countries the average age of women at first marriage has increased from 24.8 years in 1990 to 27.7 in 2002/2003 (OECD, 2007).

Despite the fact that pronounced changes in marriage patterns over time are documented, surprisingly no research on their impact on the incidence of divorce over time has been conducted. This paper is the first attempt to examine whether the increased marital instability is related to changing assortative mating patterns over time. To this end, we employ Austrian Register Data. Our choice can be rationalised by two facts: (i) this unique data-set covers the universe of all marriages and divorces in Austria between 1971 and 2007, and (ii) the Austrian marriage market has been affected by several waves of labour immigration, that have increased the incidence of both mixed religious and/or ethnic marriages. Furthermore, the sustained secularization of the native (traditionally Catholic) Austrian society has further altered the distribution of spouses' religious denominations. In addition, the rise in the age at first marriage has been pronounced in Austria. Since we observe all marriages formed over a period of four decades, we can analyse the patterns and changes of assortative mating over a longer period of time, and are able to assess their contributions to the rise in divorce rates. Moreover, our data allow us to examine the stability of the different dimensions of assortative mating on the risk of divorce over time. The only drawback of the data is that we observe spouses' educational attainment only 
for those with children. We, therefore, conduct our main analysis with the representative sample with all marriages and complement the argumentation about education with the smaller sample of spouses with children.

It turns out that changes in assortative mating are not related to the rising divorce rate. Neither immigration nor secularization are related to the upward trend in divorce. This outcome is the net-result of two countervailing effects: Mixed couples have (compared to a homogenous native couple) a higher risk of divorce, which is offset by a lower divorce hazard of (homogenous) non-native couples. In the case of age at marriage, we even observe that if spouses would have continued to marry at a young age, divorce rates would have increased more sharply. These results are also robust in the smaller sample of spouses with children. Moreover, changes in assortative mating in terms of education do not contribute to the trend in divorce over time as well. Most of these effects change in size over time. For instance, the destabilizing effect of mixed ethnic couples has tremendously increased, and the stabilizing effect of a higher age has somewhat decreased over time. We offer some plausible explanations for these trends. Finally, we provide some evidence based on survey data that the rising trend in divorce may be the results of changing social norms.

\section{Data and estimation strategy}

Over the last decades the incidence of divorce has increased sharply throughout the western world. Yet considerable variation in the base level and the pace in the increase in divorce rates can be observed across countries, see Figure 1. Southern European countries such as Italy or Spain, which traditionally have had very low levels of divorce rates experienced the strongest increase. In fact, in both countries divorce has been legalised rather recently (Italy: 1971, Spain: 1982). Austria, similar to other Central European countries (e.g. Germany), shows a middle ranking among OECD-member countries and exhibits a divorce rate which is on average four times higher compared to the south of Europe. Scandinavian countries (e.g. Sweden) and Great Britain used to have slightly higher rates, but they have been converging to Central European levels recently. The U.S. has by far the highest divorce rates in the world and shows exceptional patterns over time. U.S. divorce rates rose sharply starting in the mid-1960s, peaked in the early 1980s and have been declining since then.

In this paper we focus on Austria, where the quality of the available administrative data is exceptional. Surprisingly, these data have not been used so far. The only exceptions we are aware of are Diekmann and Mitter (1984); Prioux (1992, 1993). Divorce was introduced in Austria 1938. This legislation was based on the principle of fault, but also provided divorce on the ground of irretrievable breakdown. We combine data from the Austrian Marriage Register, covering all marriages from 1971 to 2007, with the Austrian Divorce Register, covering all divorces for the same time period. Our sample is based on all 1,643, 103 marriages which took place between 1971 and 2007. During our sample period two major reforms of the divorce law took place. A reform in 1978 widened divorce on the 
ground of irretrievable breakdown, and introduced divorce by mutual consent. In 1999 the principle of fault has been further attenuated. In principle, each reform may have altered the stability of existing marriages, and may also have changed the selection into marriage; an issue which we discuss in more detail below.

In order to obtain information on mortality and out-migration we match information from the Austrian Death Register and the Austrian Social Security Database (ASSD, Zweimüller et al. (2009)). We presume that if a person is still alive, but has no records in the ASSD, then s/he left Austria. This results in 126, 529 right-censored observations due to death, and 13,384 due to out-migration.

The marriage register includes information on the date of marriage, the spouses' former family status, place of residence, age at marriage, religious denomination and ethnicity. Since 1984 information on the spouses' country of birth and the number, age and sex of any premarital children is also recorded. We enhance our data set with information on community size, which is based on the decennial Austrian Census until 2002, where we impute for missing years by linear interpolation. From 2002 onwards yearly data are derived from the newly launched electronic Austrian Population Register.

After cleaning our data set we are left with 1,598,682 marriages for our main estimations. From these marriages, 373, 960 got divorced by the end of 2007. For couples with children we obtain information on the spouses' educational attainment through the Austrian Birth Register. For this important sub-sample we can examine the effect of education. Even more importantly, we will show that the exclusion of information on education has no impact on the other results.

In order to examine the effect of assortative mating on the probability of divorce over time we present non-parametric Kaplan-Meier estimates to get a first picture of changes in marital stability. The Kaplan-Meier estimator is a nonparametric estimate of the probability of staying married until at least time $t$. For observed divorce periods $t_{1}, \ldots, t_{k}$ this survivor function is given by:

$$
\hat{S}(t)=\prod_{j \mid t_{j} \leq t}\left(\frac{m_{j}-d_{j}}{m_{j}}\right)
$$

with $m_{j}$ as the number of married couples at the beginning of period $t_{j}$ and $d_{j}$ as the number of divorces in period $t_{j}$ (Cleves, Gould, Gutierrez and Marchenko, 2008).

Subsequently, to analyse the contributions of assortative mating on the duration of marriage we use Cox proportional hazard models (Cox, 1972). In such a model, the hazard rate at time $t$-i.e. the risk that a marriage dissolves at time $t$, provided it lasted that long - is explained by a non-parametric baseline hazard $h_{0}(t)$ which is augmented due to the influence of covariates $\mathbf{X}=\left(X_{1}, X_{2}, \ldots, X_{n}\right)$ :

$$
h(t \mid \mathbf{X})=h_{0}(t) \exp \left(\sum_{i=1}^{n} X_{i} \beta_{i}\right)
$$


A Cox model is flexible, because the baseline hazard remains unspecified. The coefficients are estimated by maximising the following partial likelihood function:

$$
L=\prod_{k=1}^{K}\left[\frac{\exp \left(\sum_{i=1}^{n} \beta_{i} X_{i k}\right)}{\sum_{j: t_{j} \geq t_{k}} \exp \left(\sum_{i=1}^{n} \beta_{i} X_{j i}\right)}\right]
$$

Our results are presented as hazard ratios that is the hazard rate of spouses with characteristics $\mathbf{X}^{*}$ relative to the hazard rate of the base group with characteristics $\mathbf{X}$, $\left(\frac{h\left(t \mid \mathbf{X}^{*}\right)}{h(t \mid \mathbf{X})}\right)$. We performed graphic and formal tests for the proportional hazard assumption with some mixed results; in particular with respect to the year when the union was formed. Due to the numeric difficulty of alternative specifications (Royston and Lambert, 2011) specifically with such a large data set as ours - and the ease of interpretation (given many covariates) we stick to the proportional hazard model. However, we will considerably relax these problems in Section 3.4, where we present results for specific decades separately.

We use all important dimensions of assortative mating. In particular, we look at age, ethnicity, religious denomination and educational attainment (see Table 1). We consider the effect of the spouses' age, as well as the importance of the spouses' age difference. To study ethnicity we first run a simple specification (covering the years 1971 through 2007) where we utilize the information on citizenship only. In a further step we additionally exploit information on the country of birth (available since 1984), which finally gives us nine different combinations relative to our base group. Given the Austrian institutional setting this allows us to draw conclusions about the effects of intermarriage among natives, first and further generation immigrants, as well as the impact of naturalization of foreign-born persons. With respect to religious denomination we distinguish between the two quantitatively most important religious affiliations in Austria (see Austrian Census from 2001): Catholic (73.6 percent) and no religious denomination (12.0 percent). All other religions mainly Protestants (4.7 percent) and Muslims (4.2 percent) - are lumped together. Since these other denominations are quite diverse groups, we distinguish between couples with the same and with different denominations from the residual group. This gives rise to seven possible combinations, where the marriage between two Catholics will serve as the base group. Educational attainment is captured by four categories: compulsory schooling, apprentice training, secondary school and university degree. Based on that scaling we code whether one of the spouses has higher education than the other.

As additional control variables we only include exogenous factors (i.e. pre-determined at the time of marriage): the number of pre-marital female and male children, size of the spouses' communities (at the time of marriage), as well as month and 115 district fixedeffects. It can be argued that all other factors which might also have an important impact on divorce risk are endogenous with respect to the viability of the marriage: e.g. the number of post-marital children, labour supply of either partner or marital satisfaction. If the quality of the marriage is bad and the risk of divorce is relatively high, it can be expected that both partners might invest less in marriage-specific capital, like joint children 
or joint enterprises of any kind, and that specialisation in the household might be different with corresponding changes in labour supply. For these reasons we refrain from using such potentially endogenous regressors.

Administrative data allow us to actually measure the three dimensions of assortative mating at the time of marriage. It is well known that spouses become more alike during marriage - i.e. partners may change religious denomination (Glenn, 1982) or get a new citizenship. Using changing or current information about these characteristics might therefore overestimate the degree of endogamy.

\section{Results}

Our analysis is based on two sample periods (1971-2007 and 1984-2007), since starting from 1984 additional information on the spouses is available. Further we distinguish between first and further marriages; but concentrate on the former. First marriages are couples where both spouses are in their first marriage. All other marriages are denoted as further unions. Approximately 72 percent of all marriages are first marriages. In a further step we estimate separate models for each decade. This allows us to test if the effect of the different dimensions of assortative mating has changed over time.

\subsection{Assortative mating and the increasing marital instability}

The Kaplan-Meier estimates for first marriages (see Figure 2) show survival probabilities for marriages formed in the decades from the $1970 \mathrm{~s}$ to the $2000 \mathrm{~s}$. We see monotonically declining survival probabilities over time. For instance, 84 percent of marriages formed in the $1970 \mathrm{~s}$ are still intact after 15 years, this value is only 77 percent for marriages formed in the 1990s. For further marriages - which as expected have a lower survival probability in the first place - a similar, however, less pronounced pattern can be observed (see Figure A.1 in the Web Appendix).

In order to estimate how the likelihood of divorce would have evolved over time if assortative mating patterns would not have changed, we start with a parsimonious model and enrich it stepwise. Columns (Ia) and (IIa) in Table 2 replicate the descriptive life-tables by only including dummies for the different decades in a Cox model along with district dummies. In case of first marriages we see that marriages formed in the 1980s have a 33.2 percent higher risk of divorce - compared to marriages in the 1970s, our base group. The equivalent values for marriages formed in the 1990s and in the 2000s are equal to 49.3 percent and 49.7 percent, respectively. Thus, we see an increase in divorce risk in the 1980s and in the 1990s, but not in the 2000s. For further marriages, see Column (IIa), the divorce risk has increased to a similar extent in the 1980s and in the 1990s, however, continued to increase also in the 2000s (plus 71.0 percent).

It is interesting to see if developments in assortative mating are related to the trend towards higher divorce rates over time in Austria. It turns out that if the model is extended 
by either controlling for spouses' age, ethnicity or religion, only the inclusion of age is able to affect the estimated decade effects significantly. Controlling for changing patterns of assortative mating along the dimensions of ethnicity or religion has basically no impact on the estimated decade effects. Just in the case of further marriages the divorce rate would be somewhat lower in the absence of changing assortative mating along the dimensions of ethnicity; details are provided below. All results from estimations where we introduce our different measures of assortative mating step-by-step are available upon request. Given these results, we present detailed estimation output for specifications where we first add binary indicators for groups of wife's age and spouses' age difference in Columns (Ib) and (IIb), and include then all other variables together in Columns (Ic) and (IIc).

During the last decades, Austria witnessed a sharp increase in the age at first marriage (see Table 1). While in 1971, the average age at first marriage was 21.6 for women and 24.4 for men, it increased to 24.6 for women and 26.8 for men until 1991. By 2007, the average age at marriage reached 28.8 for women and 31.6 for men. In the period from 1971 to 2007 husbands were on average 2.6 years older than their wives. The variation in the difference in age was less pronounced over time. However, one could observe a modest decrease starting in the 1970s until the 1990s, and an equivalent increase thereafter.

Partialing out the effects of age and age difference at the time of marriage in the estimations summarised in Columns (Ib) and (IIb) increases the measured divorce risk. Controlling for these age effects the decade effects would have increased to 46.6 percent (the 1980s), 95.4 percent (the 1990s) and 113.6 percent (the 2000s) for first marriages. Therefore, compared to the effects estimated above, estimated divorce hazards in the 1990s have doubled and those in the 2000s even more so. This pattern is similar for further marriages: taking age and age differences into account increases the rising trend in marriage dissolution. A simulation in Figure 3 illustrates how divorce rates would have evolved if the age of the wife at her first marriage would have been constant to its level in 1971. Note, that this simple simulation assumes that keeping wives' age groups constant has no impact on other marriage behaviour; this might not necessarily be true, since this affects the pool of never-married partners on the marriage market.

Accordingly, we find that compared to a marriage with wife's age below 20 at the time of her first marriage (her further marriage), marrying between 20 and 25 reduces the risk of divorce by 38.5 percent (29.4 percent). For the age group above 40 divorce risk is reduced by 83.2 percent ( 82.3 percent). The increment in the reduction of divorce risk declines with the age of wife. Lehrer (2008) explains the negative relationship between age and divorce risk by the so-called maturity effect, describing that individuals marrying relatively young are less informed about themselves, their spouses, and the marriage market. Further, it is beneficial for the stability of the marriage if the husband is older. Compared to the base group (same age, or husband is 0 to 3 years older), a husband between 3 and 6 years older leads to a small reduction in divorce risk of 6.8 percent. Compared to the same base group, a marriage with a wife being up to 3 years older has a 25.2 percent higher risk of divorce. If this age difference is larger than 3 years, the divorce risk more than doubles. 
In a further step we study the impact of ethnicity. Austria's post-World War II economic boom led to several waves of labour immigration. While in 1961 only 1.4 percent of the resident population where foreign citizens, this share has doubled by 1971, steadily increased over time and amounted to 8.9 percent in 2001. The two main recruitment regions were former Yugoslavia and Turkey. Though active labour recruitment was stopped by the late 1980s it had clearly lasting effects on subsequent migration inflows (e. g. due to the political crisis in the disintegrating Yugoslavia in the early 1990s) and on the current composition of the foreign resident population in Austria. In 2001, 63.2 percent of the total foreign resident population came from former Yugoslavia (45.3 percent) and Turkey (17.9 percent). Other important immigrant groups were Germans (10.2 percent) and Asians (4.9 percent). These immigration flows had a clear impact on the Austrian marriage market. While in 1971 about 94 percent of all marrying couples marrying this year consisted of two Austrians spouses, this number decreased over time (see Table 1), and was equal to 76.9 percent in 2007. Couples with one foreign and one native spouse accounted for 18.2 percent, and the remaining 4.9 percent were marriages between two foreigners. To study the impact of inter-ethnic marriages we start with a simple specification where we distinguish between couples, where the wife is a foreign citizen, the husband is a foreigner, where both spouses have the same foreign citizenship, or where both have a different foreign citizenship, and compare them with the hazard of two Austrian spouses.

As said before, including the rising participation of foreigners on the Austrian marriage market in the regressions has only negligible effects on the decade effects of first marriages, and is therefore not related to the increasing incidence of divorce over time. In the case of further marriages we find some effects. Controlling for immigration in the regressions, decreases the measured decade effects in Columns (IIa) to 25.1 percent (the 1980s), 42.2 percent (the 1990s) and 48.4 percent (the 2000s); detailed results are available on request.

In substance, our results corroborate what theory predicts (Becker, 1973, 1974; Becker, Landes and Michael, 1977) and confirm earlier studies (Kalmijn, de Graaf and Janssen, 2005): A discrepancy between the spouses' ethnic background increases the probability of divorce. Assuming that spouses' ethnic backgrounds are complements in the household production, the higher divorce risk results from comparable lower gains from mixed marriages. For instance in the case of first marriages, compared to an Austrian couple, a mixed couple has, depending on whether the wife or the husband is a foreign citizen, a 26.1 or 46.9 percent higher risk of divorce. On the other hand, a couple, where both spouses are foreigners, has a 62.4 or 41.4 percent lower risk of dissolution compared to a native couple, depending on whether they share the same foreign citizenship or not. This is in line with what one would expect on the basis of a more traditional value orientation among Yugoslav and Turkish citizens. For further marriages, we observe quite similar qualitative and quantitative effects. It seems that these two countervailing effects - the larger divorce risk of mixed couples and the lower divorce risk of a foreign couple - are almost balanced, and in sum we observe no overall impact of immigration on marital stability in Austria over time. 
Two developments have changed the distribution of religious denominations in Austria. Firstly, the outlined waves of labour immigration have increased the share of residents with religious affiliations other than Roman Catholic. The majority of immigrants from Turkey are Muslim. Immigrants from former Yugoslavia comprise Muslim, Orthodox Christians and Catholics. German immigrants are more likely Protestants. For instance, while in 1971 only 0.3 percent of the population of Austria were Muslim, this pattern has increased over time and amounted to 4.2 percent in 2001. Secondly, due to a high degree of secularization the share of Roman Catholics (1971: 87.4 percent, 2001: 73.6 percent) decreased in favor of residents without any religious affiliation (1971: 4.3 percent, 2001: 12.9 percent). Accordingly, we observe a changing composition of couples marrying in a given year over time (see Table 1), with a decrease in marriages among Catholic spouses and an increase for all other combinations. The increase in the incidence of these mixed marriages, may also reflect a downward trend in religiosity; which we can measure with our administrative data only to the extent which is captured by the rising share of spouses without denomination. Notably, in our data we find that for all combinations of husband's and wife's ethnicities all combinations of religious denominations are present, which ensures a proper identification of ethnicity and religion.

Changes in religious composition as well as the increasing prevalence of mixed-religion couples cannot explain the rising trend in divorce rates. Again, countervailing effects are almost balanced and in sum we observe no overall impact of changes in religious composition on marital stability over time. Persons who marry outside of their religion are much more likely to dissolve the marriage. Again, this is in line with theory and previous studies (Lehrer and Chiswick, 1993). Compared to the base group (a catholic couple), a marriage between a catholic spouse and a spouse with a different (or without any) denomination has a 26.4 percent (or 39.3 percent) higher divorce risk. Similarly, we observe a higher divorce likelihood (plus 40.5 percent) for mixed marriages within the group of other denominations. Marriages between spouses without any religion are also less stable (plus 22.1 percent). Marriages between spouses who both belong to the same other denomination (predominantly Muslims and Orthodox Christians) are the most stable (minus 19.6 percent). This might be due to a stability-increasing influence of religion on family life. In the case of further marriages we find the same qualitative but quantitatively less pronounced effects.

Our additional control variables show consistent results across different specifications. The larger the spouses' communities of residence (at the time of marriage) the higher the risk of divorce. This may show different family values, a higher social stigma of divorce in rural areas as compared to large cities or simply an effect of a larger supply of potential partners in a big city.

Summarising, we see a clear downward trend in marital stability in Austria across the last four decades; in the absence of changes in assortative mating divorce rates would have been even higher. On top of that, decreasing marriage rates over this period might have led to a positive selection of couples: those who refrain from marrying now may be the 
ones with lower match-quality. Our estimates of the declining trend in marriage stability (i. e. our period effects) do capture these effects. Taking this positive selection formally into account - which is beyond the current paper - would make this observed trend even stronger. Finally, our decade effects may comprise a changing selection into marriage due to two divorce law reforms attenuating the principle of fault (in 1978 and 1999). Whether the decade effects would be more or less pronounced in the absence of these two reforms is unclear, since such divorce law reforms may increase or decrease the average match quality of marrying couples (Rasul, 2006). Moreover, it is not clear whether such reforms should be considered as exogenous interventions, or rather as endogenous outcomes determined by societal forces reflecting the state of the marriage market.

\subsection{Ethnicity and country of birth}

For marriages after 1983 the spouses' country of birth is available as well. In the previous estimations we could only observe their citizenships; due to the possibility of naturalisation, this specification would mix up Austrian-born individuals with foreign-born immigrants who already got an Austrian citizenship. With this additional information we can now distinguish between four types of individuals, which gives rise to ten different pairings that allow us to look at ethnicity and origin of birth separately, and to distinguish between natives, first and second (or further) generation immigrants. In particular, we distinguish between a native Austrian (born in Austria, Austrian citizenship), a second generation immigrant without citizenship (born in Austria, no Austrian citizenship), a first generation immigrant with citizenship (not born in Austria, Austrian citizenship) and a first generation immigrant without citizenship (not born in Austria, no Austrian citizenship). It has to be said that we potentially misclassify second or further generation immigrants who already gained Austrian citizenship as a native Austrian. In the case, these misclassified persons married a native spouse - with a corresponding higher divorce probability - our estimates of a higher divorce risk of mixed couples are potentially downward biased.

We rerun our analysis with this more elaborate specification of ethnic background and include also some additional control variables available for this sample period. As before, we use two native Austrians as our base group. Looking at Table 3, this specification confirms the basic results from above, and provides further insights. Again, we find that including the rising share of spouses with migration background has little overall impact on long-run divorce trends and homogenous couples have a lower divorce risk compared to mixed ones. Relative to the base group, we see that couples with a joint migration background do fare better in terms of marriage stability, whereas those of a mixed background fare worse. Within immigrants, those 'closer' to the Austrian society - either those in the second generation or those having gained Austrian citizenship over time - are also closer to the Austrians in terms of marital stability: we see that the lowest divorce risk is encountered by two first generation immigrants without Austrian citizenship (minus 59 percent).

Among mixed couples, consisting of a native Austrian and an immigrant, the more 
dissimilar they are, the higher their relative divorce risk; a native Austrian and a first generation immigrant without Austrian citizenship have the highest likelihood of divorce (plus 50.5 percent). Table A.2 in the Web Appendix re-arranges the results to highlight the added value of this specification. For further marriages, we observe similar qualitative and quantitative effects.

Further control variables in Table 3 concern the impact of pre-marital joint children which are found to increase the divorce risk of first marriages. The effect is more pronounced for girls versus boys (2.4 versus 0.1 percent).

Finally, it can be noted that our results are robust to controlling for whether the spouses were living together before marriage (information available since 1989; results not presented in the paper). This pre-marital cohabitation itself is correlated with a higher risk of divorce in the 1990s and with a lower risk in the 2000s, though the latter effect is small. Such varying effects over time are in line with other research (Reinhold, 2010). To what extent this result is driven by self-selection or is a true causal effect is hard to assess (Svarer, 2004; Mazzuco, 2009).

\subsection{The effect of education}

The estimations we presented so far did not control for the spouses' education. Fortunately, we can use the important sub-sample of spouses with children - which account for more than 65 percent of all couples - to check whether the exclusion of this information is innocuous. To control for education we include the wives' educational attainment (with four binary variables: compulsory schooling, apprentice training, high school, university degree) and binary variables capturing whether the spouses have a similar level of educational attainment (base group), and whether the husband or the wife has a higher level. As Table 1 shows, the share of spouses with a similar level of educational attainment has been pretty stable over time (about 65 percent). However, the share of couples where the husband has more education has decreased in favor of couples with relatively better educated wives.

In Table 3 in Columns (Ib') and (Ic') we first show estimation results for spouses with children based on the previous specifications (without controlling for education). A comparison with the respective Columns (Ib) and (Ic) from the same Table shows that the decade effects are the same across parents and non-parents in the 1990s, however a bit smaller for parents in the 2000s. This suggests, that the increase in marital instability in the 2000s is to a larger extent driven by couples without children. The impact of assortative mating along the most dimensions is also quite similar among these two groups. In a second step we add the information on the spouses' education, see Columns (Ib' + ed.) and (Ic' + ed.). We can see that the inclusion of this information has practically no impact on the aforementioned results. The quantitative impact of the decade of marriage and the spouses' characteristics is almost unchanged. Therefore, we are confident that the exclusion of spouses' education in the basic results discussed above does not introduce an 
omitted variable bias.

Theoretically, there are two different effects of education on the risk to divorce. On the one hand, education typically reduces the degree of the division of labour between spouses and thus lowers the gains from marriage. On the other hand, highly educated spouses have greater gains of marriage - at any given division of labour - because of their high level of market and non-market skills (e.g. communication skills) (Becker et al., 1977). Moreover, spouses with higher education may select their partners more carefully. For Austria we find that highly educated spouses are less likely to divorce. For instance, a couple where the wife has a university degree is (compared to a wife with compulsory schooling only) ceteris paribus by 63.1 percent less likely to divorce. This is in line with the prediction that higher education increases the gains from marriage at any level of specialisation.

Our results for assortative mating confirm traditional views about division of labour. Couples where the husband has higher educational attainment are - compared to spouses with a similar level - less likely to divorce (minus 17 percent). The reverse can be observed for couples with relatively better educated wives (plus 26.4 percent). That means, any combination of spouses' educational attainment that would imply a specialisation that deviates from the traditional division of labour decreases marital stability.

\subsection{The impact of assortative mating over time}

Due to our long data set, covering four decades, we can look at patterns and consequences of assortative mating over time. It is a priori not clear whether the overall decrease in homogamy should increase or decrease the penalty for a mixed religious or ethnic marriage in terms of divorce risk. On the one hand, one could think that increased immigration and sustained secularization has reduced the importance of ethnicity and religion in social life, and one would expect a convergence of homogeneous and heterogeneous couples in terms of marital stability. On the other hand, compositional effects might work in the other direction: mixed marriages now may be composed of persons form cultures which areon average - farther apart. Moreover, secularization which is prevalent among Christian denominations might be less prevalent among Muslims. In sum, it remains an empirical question if and how the overall decrease in homogamy affects the relative divorce hazard of mixed couples.

In general, there is little research on the stability of determinants of divorce over different marriage cohorts. Teachman (2002) analyses marriages formed between 1950 and 1984 based on U.S. retrospective survey data, and finds that with the exception of race (convergence of divorce hazards of whites and blacks) the effects of major socio-demographic predictors have not changed over time. De Graaf and Kalmijn (2006), also employing retrospective survey data (Dutch marriage cohorts from 1942 through 1999), corroborate the basic results of Teachman (2002). They find in general no changes in divorce risk factors over time; the only exception is educational attainment. The effect of education has changed from a positive to a negative effect. However, the authors admit that larger 
data-sets may be necessary to identify trends in determinants of divorce over time.

Our estimations, separately done for each decade, are summarised for first marriages in Table 4 (and for further marriages in Table A.3 in the Web Appendix). The results reveal that the stabilizing effect of a higher age at the time of marriage has somewhat decreased over time. While in the 1970s a wife of age 20 to 25 has 41.9 percent lower divorce risk compared to age group of below 20 years, the effect slightly decreased to 39.8 percent in the 1990s and 36.5 percent in the 2000s. Marriages with wives older than 40 at their first marriage are 5 percentage points less stable in the 2000s than in the 1970s. Overall the pattern of effects across age groups does not change over time. If a positive selection into marriage is, in particular, preventing very young couples from marrying, our trend may also be explained by this selection effect.

The impact of age difference between husband and wife for first marriages changes for some age difference groups. Compared to the base group, a 3-6-years older husband reduces divorce risk by 11.2 percent in the 1970s but there is no significant difference in the 2000s. While a more than 6 years older husband in the 1970s is associated with a 16.6 percent lower divorce risk, the effect turns into a 7.4 percent higher divorce risk in the 2000s. The higher divorce risk for couples with a wife which is at least 3 years older increased from 88.2 percent in the 1970s to 134.3 in the 2000s. Similar but less pronounced trends can be observed for further marriages. Stevenson and Wolfers (2007) argue that production complementarities are less and less relevant for marriage in the western world, and consumption complementarities and the insurance motive gain importance. Given that our findings could indicate that a higher age (difference) at marriage is important to realise production complementarities (such as specialisation), but it is detrimental with respect to consumption complementarities (i.e. enjoying certain hobbies together or shared social ties) and risk sharing.

In terms of nationality, we find that the destabilizing effect of marriages between natives and immigrants has tremendously increased over time, this applies both to first as well as further marriages and is particularly severe if a non-Austrian husband is involved. If the wife is a foreign citizen, the couple faces a 16.5 percent higher divorce risk - as compared to an Austrian couple - in the 1970s, this difference increases up to 48.6 percent for marriages formed in the 2000s. If the husband is a foreign citizen, the couple's divorce risk is 11.4 percent higher as for a native couple in the 1970s; the respective difference increases to about 100 percent in the 2000s. These patterns are even stronger in the case of further marriages. Several reasons could explain this development. For instance, it might be that mixed-ethnic marriages in the 1970s were formed with different partners as in the 2000s. Looking at the evolution of mixed marriages over time, we see that in the 1970s almost 40 percent of all mixed marriages of Austrians were with ethnic-similar Germans and Swiss, who speak the same language. Indeed, this share went down to about 11 percent after 2000. During this time, the share of Austrian mixed marriages with immigrants from former Yugoslavia and Turkey increased considerably. This development offers a very plausible explanation for our empirical findings. In the case of marriages among foreigners, 
we see for couples with the same and with different non-Austrian citizenship, that their initially relatively low divorce risk is rising over time. However, for each group we still observe in the 2000s a (compared to an Austrian couple) significantly lower divorce risk (minus 51.2 and minus 14.8 percent).

For mixed marriages in terms of religion, the patterns are similar, however, in most of the cases less pronounced. For both, first and further marriages, we observe an increase in the relative divorce risk of all four types of mixed couples (with the strongest increase for spouses with mixed other denominations). It seems that — though religious endogamy is declining - the integration of different religious denominations is still challenging. The relative divorce risk of spouses without religious denomination is slightly decreasing for first marriages and quite stable for further marriages. The former effect may reflect the attenuation of the negative selection of this group due to an increasing secularization. For first marriages between spouses from the same other denomination, we find an increasing marital stability.

Estimation results based on the sample period from 1984 to 2007 including information on the spouses' country of birth and joint premarital children show that couples with mixed immigration background experienced the strongest increase in divorce hazards since the 1980s: The relative divorce risk of a native Austrian and a first generation immigrant without Austrian citizenship increased by 38.8 percentage points. However, at the same time some convergence of couples with a joint migration background (e.g. two first generation immigrants without Austrian citizenship, or a second and a first generation immigrant, both without Austrian citizenship) to Austrian couples in terms of higher levels of marital instability can be observed. Detailed estimation output is available in Table A.4 of the Web Appendix.

Concerning previous joint children these results show a remarkable change over time: while in the first periods, the existence of pre-marital children was detrimental for marital stability, this pattern has reversed later on. This result can be explained by a changing process of self-selection. Traditionally, cohabitation and in particular out-of-wedlock births have been deemed as morally wrong and were very uncommon in Austria. Unmarried expectant parents, were usually — irrespective of the length of their relationship or their match-quality - expected to marry before childbirth. That means, spouses with premarital children used to be a very selective group, supposedly with non-traditional family values and an inherent low marital stability. Over time, however, the incidence of cohabitation with or without subsequent marriage has increased, and it became a more and more accepted social institution, even in the presence of children. Accordingly, the self-selection process in pre-marital births may have changed, the group with pre-marital children has become less selective, and the correlation with an inherent low marital stability should have attenuated over time. The stabilizing effect of pre-marital children in the 2000s can be explained by the increasing dominance of a true causal effect of pre-marital children on marital stability, i. e. due to an increase in marital-specific capital and/or other dimensions of self-selection. An example for the latter is a correlation of the presence of pre-marital 
children with a high match-quality.

Our results are in line with other studies finding a different effect of male and female children on the likelihood of divorce (see, for instance, Bedard and Deschenes, 2005). The destabilizing effect in the 1980s and in the 1990s was higher for girls compared to boys, and the stabilizing effect in the 2000s more pronounced for boys. Given that Dahl and Moretti (2008) point out that the sex of the first child may influence subsequent fertility behaviour, in a robustness check we have restricted our estimation sample to spouses with only one pre-marital child; the sex differences remain. The estimation results (not presented in the paper) show that the risk of divorce is slightly higher if the child is female.

Finally, in order to study the baseline hazard of further marriages in more depth, we pool first and further marriages and control for the presence of one or two spouses with divorce experience with a binary variable. Untabulated results show that further marriages are on average twice as likely to divorce compared to first marriages. Equivalent estimations by decade show that this higher baseline hazard has even increased over time. While further marriages faced a 83.1 percent higher divorce risk - compared to first marriages - in the 1970s, the effect increased to 95.5 percent in the 2000s (detailed results are available upon request). The overall contribution of the higher divorce hazard of further marriages to the rise in the divorce rate is, however, modest. In another simulation in Figure 3 we assume that the decade-specific divorce hazards of further marriages equal that of first marriages. The resulting hypothetical divorce rate is significantly lower than the actual ones, however, the difference is only modest.

\subsection{Attitudes towards divorce}

Our analysis so far has shown that the steady increase in divorce risk cannot be attributed to changing assortative mating patterns over time. It must be due to changes in behaviour, most likely triggered by social changes. Divorce is nowadays a more acceptable way to solve a marriage crisis as some decades ago.

Survey data could provide one way to test this supposition. Unfortunately, we are not aware of any survey providing consistent information on the Austrian's attitude toward divorce over the whole time period under consideration. Still, the European and World Values Survey (E/WVS) at least provides information on the attitude towards divorce of Austrian respondents for the year 1990 and 1999. In particular, respondents are asked to evaluate on a ten-point scale whether they think 'divorce can always be justified, never be justified, or something in between'. The data shows that from 1990 to 1999 divorce became more acceptable among all sub-groups of the Austrian population (see Figure A.5 in the Web Appendix). For married respondents we observe an increase in the average score by 18.9 percent from 4.6 to 5.5. At both points in time divorced respondents consider divorce to be more justifiable than their married counterparts (1990: 7.2, 1999: 7.8), but the increase over time is relatively smaller: plus 9.3 percent. The strongest increase (plus 24.4 percent) can be observed among respondents with other family status (i.e. single, 
widowed, and separated persons).

This strong increase in the acceptance of divorce over time is robust when we control for a number of socio-economic characteristics within a regression framework based on individual data; detailed regression output is provided in Table A.5 in the Web Appendix. The acceptance of divorce increases ceteris paribus by about 0.70 points from 1990 to 1999 . If we additionally include an indicator for individual religiosity, this effect even increases to about 0.75 points. For Germany, which is culturally quite similar to Austria, the E/WVS provides data on the same question starting already in 1981. An equivalent regression analysis for West Germany shows that acceptance of divorce increases ceteris paribus by about 0.74 points from 1981 to 1990. This is a good indication that in Austria at least since the 1980s an increase in the acceptance of divorce took place.

\section{Conclusions}

Several developments, such as increased economic independence of women, waves of immigration and ongoing secularization hit marriage markets in the western world over the last decades and have altered assortative mating patterns considerably. Over the same time period a sharp increase in divorce rates could be observed. Based on the universe of all Austrian marriages since 1971 we have documented that changes in assortative mating along the dimensions of age, ethnicity and religion or education are, however, not responsible for the increased marital instability. Without the rise in the age at marriage, the incidence of divorce would have been even higher. Immigration, secularization, and the resulting supply of spouses with diverse ethnicity and religious denominations had no overall effect on divorce rates. Two countervailing effects equalize each other: Mixed couples have - compared to a homogenous native couples - a higher risk of divorce, which is offset by a lower divorce hazard of homogenous non-native couples. As a residual explanation for the increase in marital stability, we suggest changing social norms. Indeed, available survey data show that the acceptance of divorce has increased among all sub-groups of the population.

Note, that we concentrate in our analysis of assortative mating only on - at the time of marriage - pre-determined variables, like age, ethnicity and religion. We deliberately refrain from looking at other indicators typically used to predict marriage stability like the number of children or labour market participation, because for those cases endogeneity problems abound. A further step in future analysis should be to look at determinants of marriage behaviour to cover issues of selection into certain types of marriages.

To what extent can these findings be generalised to other countries? Many other OECD member countries have experienced very comparable socio-demographic developments, and similar trends in marriage and divorce (see, for instance, OECD, 2007). Moreover, our estimated determinants of divorce in Austria are quite comparable with results from other countries found in the literature. This suggests that similar results could be found in other OECD member countries as well, if similar analyses were conducted on comparable data. 
In general, we hope that our research stimulates the debate on the causes of the drastic rise in divorce rates. The interrelation of demographic changes and social norms seems to be a particularly promising route to understand this socially very important pattern.

\section{References}

Aassve, Arnstein, Gianni Betti, Stefano Mazzuco and Letizia Mencarini (2007), 'Marital Disruption and Economic Well-being: A Comparative Analysis', Journal of the Royal Statistical Society: Series A (Statistics in Society) 170(3), 781-799.

Allen, Douglas W. (1992), 'Marriage and Divorce: Comment', American Economic Review $\mathbf{8 2}(3), 679-685$.

Amato, Paul R. (2000), 'The Consequences of Divorce for Adults and Children', Journal of Marriage and Family 62(4), 1269-1287.

Becker, Gary S. (1973), 'A Theory of Marriage: Part I', Journal of Political Economy 81(4), 813-846.

Becker, Gary S. (1974), 'A Theory of Marriage: Part II', Journal of Political Economy $\mathbf{8 2}(2)$, S11-S26.

Becker, Gary S. (1993), A Treatise on the Family, Enlarged Edition, Harvard University Press, Cambridge, MA.

Becker, Gary S., Elisabeth M. Landes and Robert T. Michael (1977), 'An Economic Analysis of Marital Instability', Journal of Political Economy 85(6), 1141-1187.

Bedard, Kelly and Olivier Deschenes (2005), 'Sex Preferences, Marital Dissolution, and the Economic Status of Women', Journal of Human Resources 40(2), 411-434.

Blanchflower, David G. and Andrew J. Oswald (2004), 'Well-being Over Time in Britain and the USA', Journal of Public Economics 88(7-8), 1359-1386.

Bodenhorn, Howard (2006), 'Colorism, Complexion Homogamy, and Household Wealth: Some Historical Evidence', American Economic Review 96(2), 256-260.

Cleves, Mario A., William W. Gould, Roberto G. Gutierrez and Yulia U. Marchenko (2008), An Introduction to Survival Analysis Using Stata, Stata Press, Texas.

Cox, David R. (1972), 'Regression Models and Life-Tables', Journal of the Royal Statistical Society: Series B (Methodological) 34(2), 187-220.

Dahl, Gordon B. and Enrico Moretti (2008), 'The Demand for Sons', Review of Economic Studies 75(4), 1085-1120.

De Graaf, Paul M. and Matthijs Kalmijn (2006), 'Change and Stability in the Social Determinants of Divorce: A Comparison of Marriage Cohorts in the Netherlands', European Sociological Review 22(5), 561-572.

Diekmann, Andreas and Peter Mitter (1984), A Comparison of the 'Sickle Function' with Alternative Stochastic Models of Divorce Rates, in A.Diekmann and P.Mitter, eds, 'Stochastic Modelling of Social Processes', Academic Press, New York, pp. 123-153. 
Ermisch, John (2003), An Economic Analysis of the Family, Princeton University Press, Princeton, NJ.

Friedberg, Leora (1998), 'Did Unilateral Divorce Raise Divorce Rates? Evidence from Panel Data', American Economic Review 88(3), 608-627.

Glenn, Norval D. (1982), 'Interreligious Marriage in the United States: Patterns and Recent Trends', Journal of Marriage and the Family 44(3), 555-566.

González, Libertad and Tarja Viitanen (2009), 'The Effect of Divorce Laws on Divorce Rates in Europe', European Economic Review 53(2), 127-138.

Gruber, Jonathan (2004), 'Is Making Divorce Easier Bad for Children? The Long Run Implications of Unilateral Divorce', Journal of Labor Economics 22(4), 799-833.

Gullickson, Aaron (2006), 'Education and Black-White Interracial Marriage', Demography 43(4), 673-689.

Haerkoenen, Juho and Jaap Dronkers (2006), 'Stability and Change in the Educational Gradient of Divorce. A Comparison of Seventeen Countries', European Sociological Review 22(5), 501-517.

Halla, Martin (forthcoming), 'The Effect of Joint Custody on Family Outcomes', Journal of the European Economic Association .

Kalmijn, Matthijs (1991a), 'Shifting Boundaries: Trends in Religious and Educational Homogamy', American Sociological Review 56(6), 786-800.

Kalmijn, Matthijs (1991b), 'Status Homogamy in the United States', American Journal of Sociology 97(2), 496-523.

Kalmijn, Matthijs (1998), 'Intermarriage and Homogamy: Causes, Patterns, Trends', Annual Review of Sociology 24, 395-421.

Kalmijn, Matthijs, Paul M. de Graaf and Jacques P.G. Janssen (2005), 'Intermarriage and the Risk of Divorce in the Netherlands: The Effects of Differences in Religion and in Nationality, 1974-94', Population Studies 59(1), 71-85.

Kitson, Gay C. and Leslie A. Morgan (1990), 'The Multiple Consequences of Divorce: A Decade Review', Journal of Marriage and the Family 52(4), 913-924.

Lehrer, Evelyn L. (2008), 'Age at Marriage and Marital Instability: Revisiting the BeckerLandes-Michael Hypothesis', Journal of Population Economics 21(2), 463-484.

Lehrer, Evelyn L. and Carmel U. Chiswick (1993), 'Religion as a Determinant of Marital Stability', Demography 30(3), 385-404.

Mare, Robert D. (1991), 'Five Decades of Educational Assortative Mating', American Sociological Review 56(1), 15-32.

Mazzuco, Stefano (2009), 'Another Look into the Effect of Premarital Cohabitation on Duration of Marriage: An Approach Based on Matching', Journal of the Royal Statistical Society: Series A (Statistics in Society) 172(1), 255-273.

OECD (2007), Society at a Glance: OECD Social Indicators 2006, OECD, Paris. 
Pencavel, John (1998), 'Assortative Mating by Schooling and the Work Behavior of Wives and Husbands', American Economic Review 88(2), 326-329.

Peters, Elizabeth H (1986), 'Marriage and Divorce: Informational Constraints and Private Contracting', American Economic Review 76(3), 437-454.

Peters, Elizabeth H. (1992), 'Marriage and Divorce: Reply', American Economic Review 82(3), 686-693.

Prioux, France (1992), 'Influence du mois de mariage sur la propension á divorcer. Le cas de l'Autriche', Population (French Edition) 47(5), 1306-1313.

Prioux, France (1993), 'The Ups and Downs of Marriage in Austria', Population: An English Selection 5, 153-182.

Rasul, Imran (2006), 'Marriage Markets and Divorce Laws', Journal of Law, Economics and Organization 22(1), 30-69.

Reinhold, Steffen (2010), 'Reassessing the Link Between Premarital Cohabitation and Marital Instability', Demography 47(3), 719-733.

Richards, M., R. Hardy and M. Wadsworth (1997), 'The Effects of Divorce and Separation on Mental Health in a National UK Birth Cohort', Psychological Medicine 27(5), 11211128 .

Rosenfeld, Michael J. (2008), 'Racial, Educational and Religious Endogamy in the United States: A Comparative Historical Perspective', Social Forces 87(1), 1-31.

Royston, Patrick and Paul C. Lambert (2011), Flexible Parametric Survival Analysis Using Stata: Beyond the Cox Model, Stata Press, College Station.

Schwartz, Christine R. and Robert D. Mare (2005), 'Trends in Educational Assortative Marriage from 1940 to 2003', Demography 42(4), 621-646.

Smits, Jeroen, Wout Ultee and Jan Lammers (2000), 'More or Less Educational Homogamy? A Test of Different Versions of Modernization Theory Using Cross-Temporal Evidence for 60 Countries', American Sociological Review 65(5), 781-788.

Stevenson, Betsey and Justin Wolfers (2007), 'Marriage and Divorce: Changes and their Driving Forces', Journal of Economic Perspectives 21(2), 27-52.

Svarer, Michael (2004), 'Is Your Love in Vain? Another Look at Premarital Cohabitation and Divorce', Journal of Human Resources 39(2), 523-535.

Teachman, Jay (2002), 'Stability Across Cohorts in Divorce Risk Factors', Demography 39(2), 331-351.

Wolfers, Justin (2006), 'Did Unilateral Divorce Laws Raise Divorce Rates? A Reconciliation and New Results', American Economic Review 96(5), 1802-1820.

Zweimüller, Josef, Rudolf Winter-Ebmer, Rafael Lalive, Andreas Kuhn, Jean-Philipe Wuellrich, Oliver Ruf and Simon Buchi (2009), Austrian Social Security Database, Working Paper 0903, NRN: The Austrian Center for Labor Economics and the Analysis of the Welfare State. 


\section{$5 \quad$ Figures}

Figure 1: Divorce rates for selected countries, 1970-2005

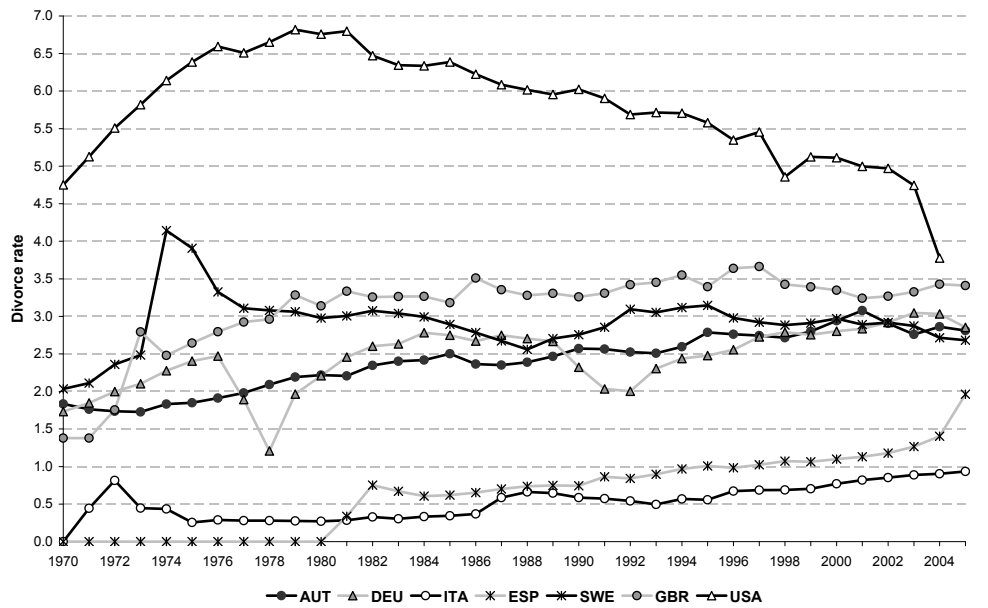

${ }^{a}$ Number of divorces per 1,000 of the population 15 years of age or older. The figures for the European countries are own calculations based on data from Eurostat. The figures for the United States are own calculation based on data from several editions of the National Vital Statistics Reports published by the National Center for Health Statistics and the Reading Survey of Epidemiology and End Results (SEER) U.S. County Population Data provided by the National Bureau of Economic Research.

Figure 2: Kaplan-Meier estimators for the duration of first marriages by decade

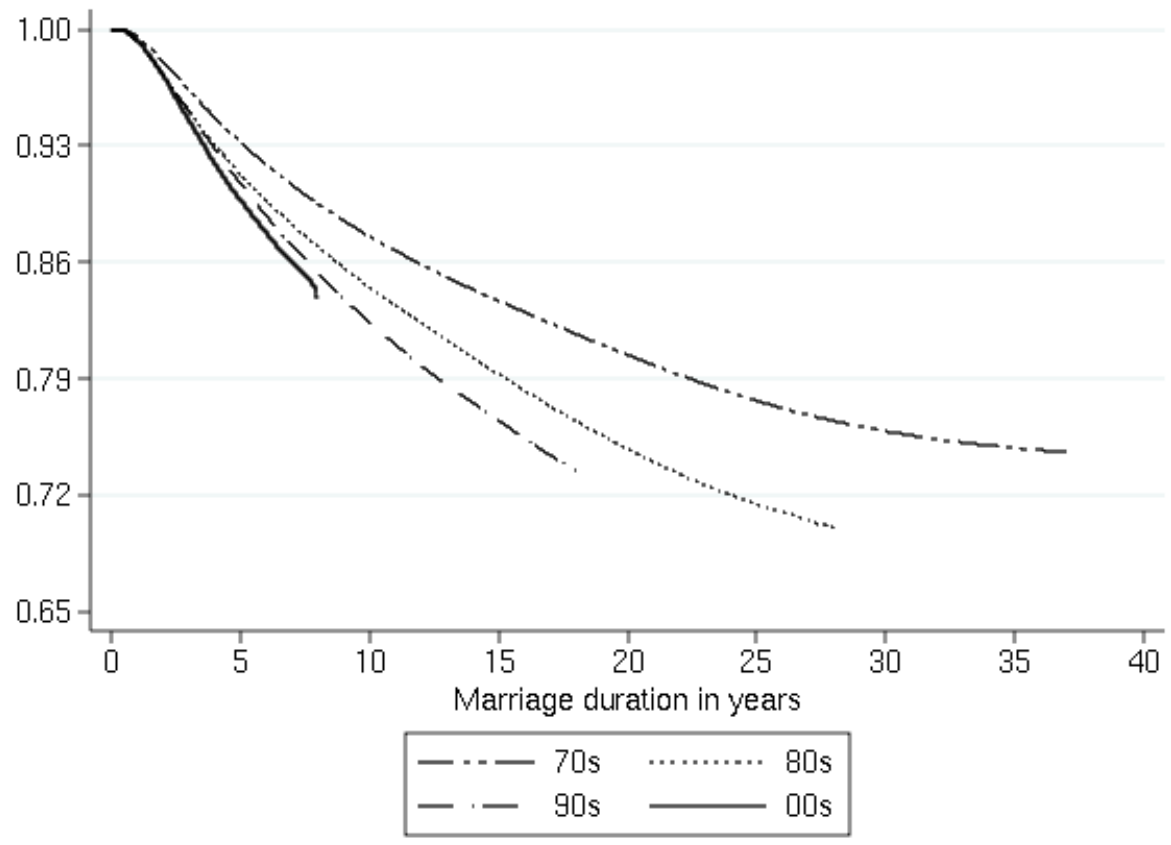


Figure 3: Actual and simulated divorce $\operatorname{rates}^{a}$

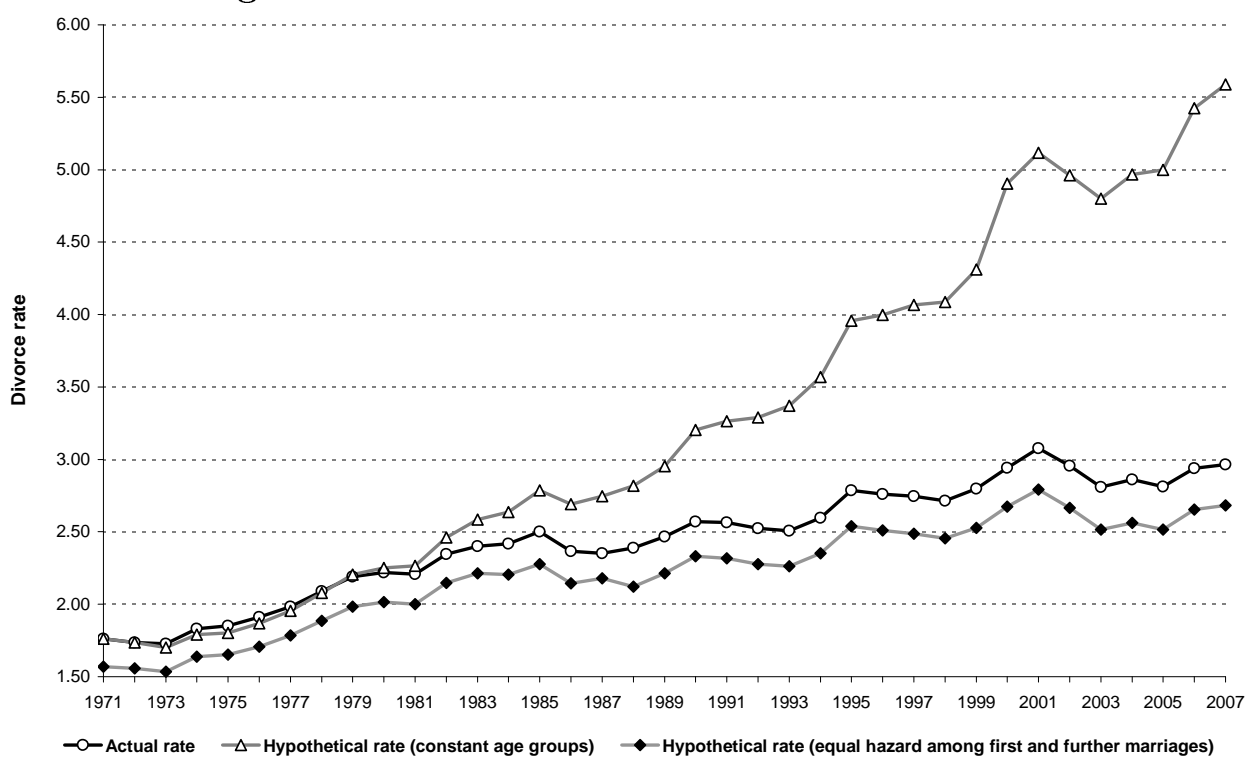

${ }^{a}$ Number of divorces per 1,000 of the population 15 years of age or older. 


\section{Tables}

Table 1: Assortative mating over time: Descriptives

\begin{tabular}{|c|c|c|c|c|c|}
\hline & \multicolumn{5}{|c|}{ Years } \\
\hline & 1971 & 1981 & 1991 & 2001 & 2007 \\
\hline \multicolumn{6}{|l|}{ Age and age difference } \\
\hline Avg. age of bride & 21.6 & 22.1 & 24.6 & 27.3 & 28.8 \\
\hline Avg. age of groom & 24.4 & 24.7 & 26.8 & 30.0 & 31.6 \\
\hline Avg. age difference & 2.71 & 2.67 & 2.25 & 2.68 & 2.80 \\
\hline \multicolumn{6}{|l|}{ Citizenship } \\
\hline Both are Austrian & 94.06 & 91.83 & 84.48 & 74.89 & 76.92 \\
\hline One spouse is foreigner & 5.24 & 6.57 & 11.89 & 20.88 & 18.19 \\
\hline Both have same foreign citizenship & 0.54 & 1.89 & 3.17 & 2.82 & 2.87 \\
\hline Mmixed foreign citizenship & 0.15 & 0.15 & 0.46 & 1.41 & 2.01 \\
\hline \multicolumn{6}{|l|}{ Religious denomination } \\
\hline Both catholic & 82.37 & 79.94 & 69.28 & 55.95 & 52.43 \\
\hline Catholic, undenominational & 3.92 & 5.52 & 8.90 & 13.64 & 15.34 \\
\hline Both undenominational & 0.85 & 1.58 & 4.53 & 9.00 & 11.32 \\
\hline Catholic, other denomination & 9.83 & 9.57 & 11.40 & 10.75 & 8.90 \\
\hline Other denomination, undenominational & 0.70 & 1.00 & 1.98 & 3.57 & 3.56 \\
\hline Both have same other denomination & 2.22 & 2.21 & 4.53 & 6.43 & 7.77 \\
\hline Mixed other denomination & 0.11 & 0.18 & 0.51 & 0.66 & 0.68 \\
\hline \multicolumn{6}{|l|}{ Education $^{a}$} \\
\hline Both have same education level & & & 66.21 & 66.30 & 65.17 \\
\hline Husband has higher education & & & 21.93 & 17.63 & 16.58 \\
\hline Wife has higher education & & & 11.86 & 16.07 & 18.25 \\
\hline
\end{tabular}


Table 2: Determinants of divorce risk: $1971-2007^{a}$

\begin{tabular}{|c|c|c|c|c|c|c|c|c|}
\hline & \multicolumn{4}{|c|}{ FiRST MARRIAGES } & \multicolumn{4}{|c|}{ FURTHER MARRIAGES } \\
\hline & Share & (Ia) & $(\mathrm{Ib})$ & (Ic) & Share & (IIa) & (IIb) & (IIc) \\
\hline \multicolumn{9}{|l|}{ Decade fixed-effects } \\
\hline 1970s (base group) & $27.35 \%$ & 1 & 1 & 1 & $21.43 \%$ & 1 & 1 & 1 \\
\hline $1980 \mathrm{~s}$ & $31.65 \%$ & $1.332 \dagger$ & $1.466 \dagger$ & $1.479 \dagger$ & $26.19 \%$ & $1.288 \dagger$ & $1.339 \dagger$ & $1.312 \dagger$ \\
\hline $1990 \mathrm{~s}$ & $25.28 \%$ & $1.493 \dagger$ & $1.954 \dagger$ & $2.016 \dagger$ & $28.67 \%$ & $1.541 \dagger$ & $1.776 \dagger$ & $1.663 \dagger$ \\
\hline $2000 \mathrm{~s}$ & $15.72 \%$ & $1.497 \dagger$ & $2.136 \dagger$ & $2.136 \dagger$ & $23.71 \%$ & $1.710 \dagger$ & $2.220 \dagger$ & $1.947 \dagger$ \\
\hline \multicolumn{9}{|l|}{ Age of Wife } \\
\hline $15-20$ years (base group) & $16.90 \%$ & & 1 & 1 & $1.95 \%$ & & 1 & 1 \\
\hline $21-25$ years & $45.67 \%$ & & $0.615 \dagger$ & $0.601 \dagger$ & $12.94 \%$ & & $0.706 \dagger$ & $0.712 \dagger$ \\
\hline $26-30$ years & $25.29 \%$ & & $0.392 \dagger$ & $0.371 \dagger$ & $20.63 \%$ & & $0.496 \dagger$ & $0.502 \dagger$ \\
\hline $31-35$ years & $8.60 \%$ & & $0.281 \dagger$ & $0.257 \dagger$ & $19.95 \%$ & & $0.366 \dagger$ & $0.374 \dagger$ \\
\hline $36-40$ years & $2.41 \%$ & & $0.212 \dagger$ & $0.191 \dagger$ & $15.27 \%$ & & $0.289 \dagger$ & $0.293 \dagger$ \\
\hline $40+$ years & $1.13 \%$ & & $0.168 \dagger$ & $0.148 \dagger$ & $29.26 \%$ & & $0.177 \dagger$ & $0.181 \dagger$ \\
\hline \multicolumn{9}{|l|}{ Age difference } \\
\hline Same Age/Husband is older: $0-3$ years & $38.33 \%$ & & 1 & 1 & $16.17 \%$ & & 1 & 1 \\
\hline Husband is older: $3-6$ years & $26.53 \%$ & & $0.932 \dagger$ & $0.933 \dagger$ & $15.57 \%$ & & $0.882 \dagger$ & $0.884 \dagger$ \\
\hline Husband is older: 6 or more years & $15.70 \%$ & & $0.952 \dagger$ & $0.931 \dagger$ & $38.92 \%$ & & $0.753 \dagger$ & $0.745 \dagger$ \\
\hline Wife is older: $0-3$ years & $14.66 \%$ & & $1.252 \dagger$ & $1.248 \dagger$ & $12.09 \%$ & & $1.131 \dagger$ & $1.114 \dagger$ \\
\hline Wife is older: 3 or more years & $4.78 \%$ & & $2.019 \dagger$ & $1.937 \dagger$ & $17.25 \%$ & & $1.720 \dagger$ & $1.591 \dagger$ \\
\hline \multicolumn{9}{|l|}{ Citizenship } \\
\hline Both are Austrian (base group) & $89.85 \%$ & & & 1 & $80.72 \%$ & & & 1 \\
\hline Husband is Austrian/wife is foreigner & $4.00 \%$ & & & $1.261 \dagger$ & $9.28 \%$ & & & $1.296 \dagger$ \\
\hline Husband is foreigner/wife is Austrian & $3.31 \%$ & & & $1.469 \dagger$ & $7.52 \%$ & & & $1.817 \dagger$ \\
\hline Both have same foreign citizenship & $2.35 \%$ & & & $0.376 \dagger$ & $1.79 \%$ & & & $0.452 \dagger$ \\
\hline Mixed foreign citizenship & $0.49 \%$ & & & $0.586 \dagger$ & $0.69 \%$ & & & $0.665 \dagger$ \\
\hline \multicolumn{9}{|l|}{ Religious denomination } \\
\hline Both catholic (base group) & $78.62 \%$ & & & 1 & $53.08 \%$ & & & 1 \\
\hline Catholic, undenominational & $5.43 \%$ & & & $1.393 \dagger$ & $16.48 \%$ & & & $1.086 \dagger$ \\
\hline Both undenominational & $2.51 \%$ & & & $1.221 \dagger$ & $9.02 \%$ & & & 0.985 \\
\hline Catholic, other denomination & $8.54 \%$ & & & $1.264 \dagger$ & $13.13 \%$ & & & $1.153 \dagger$ \\
\hline Other denomination, undenominational & $1.03 \%$ & & & $1.430 \dagger$ & $3.65 \%$ & & & $1.233 \dagger$ \\
\hline Both have same other denomination & $3.64 \%$ & & & $0.804 \dagger$ & $3.97 \%$ & & & 0.995 \\
\hline Mixed other denomination & $0.23 \%$ & & & $1.405 \dagger$ & $0.67 \%$ & & & $1.403 \dagger$ \\
\hline \multicolumn{9}{|l|}{ 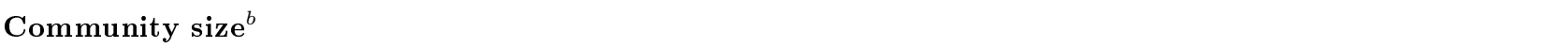 } \\
\hline Inhabitants of husband's community & & & & $1.146 \dagger$ & & & & $1.030 \dagger$ \\
\hline Inhabitants of wife's community & & & & $1.020 \dagger$ & & & & $1.012 \dagger$ \\
\hline Month fixed-effects & & no & no & yes & & no & no & yes \\
\hline District fixed-effects & & yes & yes & yes & & yes & yes & yes \\
\hline Observations & & $1,160,212$ & $1,160,212$ & $1,160,212$ & & 438,470 & 438,470 & 438,470 \\
\hline
\end{tabular}

$\bar{a}$ Estimated using a Cox (proportional hazard) model; hazard ratios with $*$ and $\dagger$ indicating statistical significance at the 5-percent and 1-percent level respectively. Columns (Ia) to (Ic) are based on first marriages and Columns (IIa) to (IIc) on further marriages. ${ }^{b}$ Inhabitants are measured in 10,000 . 
Table 3: Determinants of divorce risk: $1984-2007^{a}$

\begin{tabular}{|c|c|c|c|c|c|c|c|c|c|}
\hline & \multicolumn{4}{|c|}{ BASELINE SAMPLE } & \multicolumn{5}{|c|}{ EDUCATION SAMPLE } \\
\hline & Share & (Ia) & $(\mathrm{Ib})$ & (Ic) & Share & $\left.(\mathrm{Ib})^{\prime}\right)$ & $(\mathrm{Ib}+$ ed. $)$ & $\left(\mathrm{Ic} c^{\prime}\right)$ & $\left(\mathrm{Ic}{ }^{\prime}+\right.$ ed. $)$ \\
\hline \multicolumn{10}{|l|}{ Decade effects } \\
\hline 1980s (base group) & $31.15 \%$ & 1 & 1 & 1 & $36.17 \%$ & 1 & 1 & 1 & 1 \\
\hline $1990 \mathrm{~s}$ & $42.46 \%$ & $1.080 \dagger$ & $1.236 \dagger$ & $1.267 \dagger$ & $45.21 \%$ & $1.220 \dagger$ & $1.223 \dagger$ & $1.279 \dagger$ & $1.298 \dagger$ \\
\hline $2000 \mathrm{~s}$ & $26.39 \%$ & $1.111 \dagger$ & $1.426 \dagger$ & $1.381 \dagger$ & $18.62 \%$ & $1.236 \dagger$ & $1.248 \dagger$ & $1.269 \dagger$ & $1.304 \dagger$ \\
\hline \multicolumn{10}{|l|}{ Age of Wife } \\
\hline $15-20$ years (base group) & $8.69 \%$ & & 1 & 1 & $9.81 \%$ & 1 & 1 & 1 & 1 \\
\hline $21-25$ years & $41.11 \%$ & & $0.628 \dagger$ & $0.600 \dagger$ & $46.03 \%$ & $0.555 \dagger$ & $0.600 \dagger$ & $0.528 \dagger$ & $0.577 \dagger$ \\
\hline $26-30$ years & $33.09 \%$ & & $0.394 \dagger$ & $0.365 \dagger$ & $32.83 \%$ & $0.336 \dagger$ & $0.393 \dagger$ & $0.306 \dagger$ & $0.367 \dagger$ \\
\hline $31-35$ years & $12.30 \%$ & & $0.285 \dagger$ & $0.244 \dagger$ & $9.53 \%$ & $0.241 \dagger$ & $0.296 \dagger$ & $0.210 \dagger$ & $0.267 \dagger$ \\
\hline $36-40$ years & $3.41 \%$ & & $0.216 \dagger$ & $0.189 \dagger$ & $1.65 \%$ & $0.184 \dagger$ & $0.227 \dagger$ & $0.158 \dagger$ & $0.203 \dagger$ \\
\hline $40+$ years & $1.40 \%$ & & $0.194 \dagger$ & $0.163 \dagger$ & $0.15 \%$ & $0.142 \dagger$ & $0.174 \dagger$ & $0.121 \dagger$ & $0.152 \dagger$ \\
\hline \multicolumn{10}{|l|}{ Age difference } \\
\hline Same Age/Husband is older: $0-3$ years & $37.92 \%$ & & 1 & 1 & $39.47 \%$ & 1 & 1 & 1 & 1 \\
\hline Husband is older: $3-6$ years & $25.08 \%$ & & $0.971 \dagger$ & $0.968 \dagger$ & $26.01 \%$ & $0.963 \dagger$ & $0.961 \dagger$ & $0.967 \dagger$ & $0.966 \dagger$ \\
\hline Husband is older: 6 or more years & $15.26 \%$ & & $1.051 \dagger$ & 1.004 & $14.32 \%$ & $1.040 \dagger$ & $1.034 \dagger$ & $1.023 *$ & 1.018 \\
\hline Wife is older: $0-3$ years & $16.11 \%$ & & $1.258 \dagger$ & $1.247 \dagger$ & $15.84 \%$ & $1.336 \dagger$ & $1.305 \dagger$ & $1.334 \dagger$ & $1.299 \dagger$ \\
\hline Wife is older: 3 or more years & $5.63 \%$ & & $2.112 \dagger$ & $1.977 \dagger$ & $4.36 \%$ & $2.072 \dagger$ & $1.913 \dagger$ & $2.038 \dagger$ & $1.848 \dagger$ \\
\hline \multicolumn{10}{|l|}{ Education } \\
\hline Same education level (base group) & & & & & $66.67 \%$ & & 1 & & 1 \\
\hline Husband has higher education & & & & & $20.27 \%$ & & $0.896 \dagger$ & & $0.830 \dagger$ \\
\hline Wife has higher education & & & & & $13.06 \%$ & & $1.245 \dagger$ & & $1.264 \dagger$ \\
\hline Compulsory school - wife (base group) & & & & & $12.58 \%$ & & 1 & & 1 \\
\hline Apprenticeship - wife & & & & & $59.54 \%$ & & $0.748 \dagger$ & & $0.649 \dagger$ \\
\hline High school - wife & & & & & $15.31 \%$ & & $0.593 \dagger$ & & $0.494 \dagger$ \\
\hline University - wife & & & & & $12.57 \%$ & & $0.453 \dagger$ & & $0.369 \dagger$ \\
\hline \multicolumn{10}{|l|}{ Country of birth \& citizenship ${ }^{b}$} \\
\hline Two native Austrians (base group) & $84.34 \%$ & & & 1 & $87.59 \%$ & & & 1 & 1 \\
\hline Two SGIs, no citizenship & $0.12 \%$ & & & $0.553 \dagger$ & $0.13 \%$ & & & $0.480 \dagger$ & $0.425 \dagger$ \\
\hline Two FGIs, citizenship & $0.24 \%$ & & & 0.877 & $0.17 \%$ & & & 0.941 & 0.948 \\
\hline Two FGIs, no citizenship & $3.33 \%$ & & & $0.410 \dagger$ & $3.18 \%$ & & & $0.419 \dagger$ & $0.360 \dagger$ \\
\hline Native Austrian/SGI, no citizenship & $0.68 \%$ & & & $1.241 \dagger$ & $0.54 \%$ & & & $1.222 \dagger$ & $1.167 \dagger$ \\
\hline Native Austrian/FGI, citizenship & $2.37 \%$ & & & $1.130 \dagger$ & $2.18 \%$ & & & $1.180 \dagger$ & $1.216 \dagger$ \\
\hline Native Austrian/FGI, no citizenship & $6.85 \%$ & & & $1.505 \dagger$ & $4.61 \%$ & & & $1.316 \dagger$ & $1.272 \dagger$ \\
\hline SGI, no citizenship/FGI, citizenship & $0.10 \%$ & & & $0.826^{*}$ & $0.08 \%$ & & & 0.946 & 0.861 \\
\hline SGI, no citizenship/FGI, no citizenship & $0.44 \%$ & & & $0.508 \dagger$ & $0.46 \%$ & & & $0.467 \dagger$ & $0.411 \dagger$ \\
\hline FGI, citizenship/FGI, no citizenship & $1.52 \%$ & & & $1.134 \dagger$ & $1.06 \%$ & & & $0.801 \dagger$ & $0.735 \dagger$ \\
\hline
\end{tabular}

Continued on the next page ... 
... continued from the previous page

\section{Religious denomination}

Both catholic (base group)

Catholic, undenominational

Both undenominational

$74.08 \%$

$7.23 \%$

$3.76 \%$

$8.52 \%$

Other denomination, undenominational $1.41 \%$

Both have same other denomination $\quad 4.69 \%$

Mixed other denomination

$0.31 \%$

\section{Community size}

Inhabitants of husband's community

Inhabitants of wife's community

Pre-marital children

Number of joint male children

Number of joint female children

Month fixed-effects

District fixed-effects

Observations

$\begin{array}{ll}1 & 78.72 \% \\ 1.400 \dagger & 5.64 \% \\ 1.216 \dagger & 2.46 \% \\ 1.340 \dagger & 7.60 \% \\ 1.479 \dagger & 0.95 \% \\ 0.810 \dagger & 4.44 \% \\ 1.592 \dagger & 0.19 \%\end{array}$

\section{1}

$1.412 \dagger$

$1.117 \dagger$

$1.321 \dagger$

$1.359 \dagger$

$0.760 \dagger$

$1.408 \dagger$

\section{1} $1.397 \dagger$

$1.127 \dagger$

$1.321 \dagger$

$1.350 \dagger$

$0.730 \dagger$

$1.378 \dagger$

$1.164 \dagger$

$1.217 \dagger$

$1.235 \dagger$

$1.021 \dagger \quad 1.023 \dagger$

$1.001 \quad 0.986 \quad 0.915 \dagger$

$1.024 \dagger \quad 0.998 \quad 0.926 \dagger$

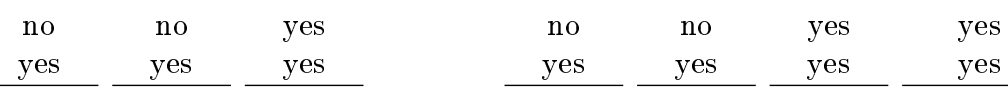

$\overline{690,509} \frac{\mathrm{yeg}}{690,509} \frac{\mathrm{yes}}{690,509} \frac{\mathrm{yes}}{451,552} \frac{\mathrm{yes}}{451,552} \frac{\mathrm{yes}}{451,552}$

\footnotetext{
${ }^{a}$ Estimated using a Cox (proportional hazard) models; hazard ratios with $*$ and $\dagger$ indicating statistical significance at the 5-percent and 1-percent level respectively. Columns (Ia) to (Ic) are based on the full sample of first marriages and Columns (Ib') to (Ic' + ed.) are based on the sub-sample of first marriages with marital children. Equivalent estimation output for the full sample of further marriages is provided in Table A.1 of the Web Appendix. 'b 'FGI' stands for first generation immigrant, 'SGI' stands for second (or further) generation immigrant.

${ }^{c}$ Inhabitants are measured in 10,000 .
} 
Table 4: Determinants of divorce risk for first marriages by decades: 1971$2007^{a}$

\begin{tabular}{|c|c|c|c|c|}
\hline & $\begin{array}{c}(\mathrm{Ia}) \\
1970\end{array}$ & $\begin{array}{c}(\mathrm{Ib}) \\
1980 \\
\end{array}$ & $\begin{array}{c}(\mathrm{Ic}) \\
1990 \\
\end{array}$ & $\begin{array}{c}(\mathrm{Id}) \\
2000\end{array}$ \\
\hline \multicolumn{5}{|l|}{ Age of Wife } \\
\hline $15-20$ years (base group) & 1 & 1 & 1 & 1 \\
\hline $21-25$ years & $0.581 \dagger$ & $0.611 \dagger$ & $0.602 \dagger$ & $0.635 \dagger$ \\
\hline $26-30$ years & $0.367 \dagger$ & $0.392 \dagger$ & $0.371 \dagger$ & $0.335 \dagger$ \\
\hline $31-35$ years & $0.259 \dagger$ & $0.276 \dagger$ & $0.271 \dagger$ & $0.219 \dagger$ \\
\hline $36-40$ years & $0.178 \dagger$ & $0.217 \dagger$ & $0.200 \dagger$ & $0.166 \dagger$ \\
\hline $40+$ years & $0.107 \dagger$ & $0.126 \dagger$ & $0.179 \dagger$ & $0.158 \dagger$ \\
\hline \multicolumn{5}{|l|}{ Age difference } \\
\hline Same Age/Husband is older: $0-3$ years & 1 & 1 & 1 & 1 \\
\hline Husband is older: $3-6$ years & $0.888 \dagger$ & $0.956 \dagger$ & $0.953 \dagger$ & 0.987 \\
\hline Husband is older: 6 or more years & $0.834 \dagger$ & $0.944 \dagger$ & 1.023 & $1.074 \dagger$ \\
\hline Wife is older: $0-3$ years & $1.265 \dagger$ & $1.249 \dagger$ & $1.232 \dagger$ & $1.265 \dagger$ \\
\hline Wife is older: 3 or more years & $1.882 \dagger$ & $1.878 \dagger$ & $1.883 \dagger$ & $2.343 \dagger$ \\
\hline \multicolumn{5}{|l|}{ Citizenship } \\
\hline Both are Austrian (base group) & 1 & 1 & 1 & 1 \\
\hline Husband is Austrian/wife is foreigner & $1.165 \dagger$ & $1.281 \dagger$ & $1.269 \dagger$ & $1.486 \dagger$ \\
\hline Husband is foreigner/wife is Austrian & $1.114 \dagger$ & $1.415 \dagger$ & $1.548 \dagger$ & $2.002 \dagger$ \\
\hline Both have same foreign citizenship & $0.303 \dagger$ & $0.342 \dagger$ & $0.426 \dagger$ & $0.488 \dagger$ \\
\hline Mixed foreign citizenship & $0.620 \dagger$ & $0.547 \dagger$ & $0.541 \dagger$ & $0.852^{*}$ \\
\hline \multicolumn{5}{|l|}{ Religious denomination } \\
\hline Both catholic (base group) & 1 & 1 & 1 & 1 \\
\hline Catholic, undenominational & $1.348 \dagger$ & $1.376 \dagger$ & $1.460 \dagger$ & $1.422 \dagger$ \\
\hline Both undenominational & $1.379 \dagger$ & $1.174 \dagger$ & $1.260 \dagger$ & $1.266 \dagger$ \\
\hline Catholic, other denomination & $1.194 \dagger$ & $1.213 \dagger$ & $1.347 \dagger$ & $1.572 \dagger$ \\
\hline Other denomination, undenominational & $1.290 \dagger$ & $1.359 \dagger$ & $1.463 \dagger$ & $1.679 \dagger$ \\
\hline Both have same other denomination & $0.879 \dagger$ & $0.881 \dagger$ & $0.744 \dagger$ & $0.732 \dagger$ \\
\hline Mixed other denomination & 1.029 & $1.378 \dagger$ & $1.483 \dagger$ & $1.706 \dagger$ \\
\hline \multicolumn{5}{|l|}{ Community size $^{b}$} \\
\hline Inhabitants of husband's community & $1.211 \dagger$ & $1.285 \dagger$ & $1.202 \dagger$ & $1.131 \dagger$ \\
\hline Inhabitants of wife's community & $1.021 \dagger$ & $1.022 \dagger$ & $1.016 \dagger$ & $1.015 \dagger$ \\
\hline Month fixed-effects & yes & yes & yes & yes \\
\hline District fixed-effects & yes & yes & yes & yes \\
\hline Observations & 317,681 & 366,789 & 293,283 & 182,459 \\
\hline
\end{tabular}

${ }^{a}$ Estimated using a Cox (proportional hazard) models; hazard ratios with $*$ and $\dagger$ indicating statistical significance at the 5-percent and 1-percent level respectively.

${ }^{b}$ Inhabitants are measured in 10,000 . 